\title{
Modification of Bullock Drawn Seed cum Fertilizer Drill for Intercropping System
}

\author{
K. Revanth*, S. Ramyashree, K. Sai Krishna, B. T. Rakesh, \\ D. Sandhya and Murkannappa \\ Department of Agril. Engg. CoA, GKVK, UAS, Bengaluru, India \\ *Corresponding author
}

\begin{tabular}{l} 
Ke y w o r d s \\
$\begin{array}{l}\text { Bullock, } \\
\text { Intercropping } \\
\text { system, Speed, } \\
\text { Seed drills }\end{array}$ \\
\hline Article Info \\
\hline $\begin{array}{l}\text { Accepted: } \\
\text { 08 January } 2020 \\
\text { Available Online: } \\
\text { 10 February } 2020\end{array}$ \\
\hline
\end{tabular}

Keywords

Bullock, Intercropping system, Speed, Article Info

Accepted: Available Online: 10 February 2020

\section{A B S T R A C T}

Sowing is prime operation in cultivation practice of any crop which directly affects production. Therefore, timely sowing is necessary with available sources of power. Intercropping being one of the traditional practices of crop production and there are no seed drills to both main crop and inter-crop in a single pass. To overcome this problem, the present seed cum fertilizer has to be modified to suit the requirement of the intercropping practice. The seed drill was modified by partitioning into 3 compartments in the seed hopper to suit the 2:1 and 8:1 intercropping ratio using two MS plates which are movable within the hopper for a predetermined distance with the help of a screw a handle mechanism. The modified seed drill was calibrated in the laboratory to check the seed rate of Redgram and soyabean. The seed rate of the both type of seed were within the recommended rates. The variation of seed flow in different furrow openers were less than $10 \%$ as recommended by the BIS. The modified seed drill was evaluated in the field condition to check its performance. The average field capacity was found to be $0.25 \mathrm{ha} / \mathrm{h}$ at a forward speed of $2.8 \mathrm{kmph}$. The average field efficiency was found to be $70 \%$.

\section{Introduction}

Planting refers to placing seeds in the soil, broadcasting seeds on the field surface or dibbling the seeds in the soil under optimum depth and moisture conditions. To get high yield, right amount of seed should be placed at the right time in a predetermined depth. Usually, the depth of sowing depends upon the moisture availability and emergence capacity. The spacing between the seeds is governed by plant growth and their distribution per unit area. However, the space requirement of a plant is so adjusted between the rows that the subsequent use of intercultural implements is made possible for the crops. In general the larger seeds are sown at comparatively greater depth and plants need wider spacing. 
The seeding equipment for unirrigated areas are designed to place the seed in firm moist soil. The moisture from the surface layer of seed bed in arid areas is evaporated quickly and germination of seeds may be adversely affected if the seeds are sown at shallow depth of four to five centimetres as done in irrigated areas. The requirements of seed drills for unirrigated areas are that it should make a furrow and place the seed in firm moist soil below in the bottom of the furrow. The multi-row seed drills/planters with packer wheels (tractor drawn and animal drawn) are designed to obtain the optimum environment for the germination of seed and growth of seedlings under unirrigated condition. The seed boots are designed to place about the seed about $4 \mathrm{~cm}$ below the bottom of the furrow made in the dry soil. Packer wheels fixed to the rear of the machine pack the soil over seed or a chain driven toothed wheel fixed to the drive shaft of the seed dropping mechanism can be set to obtain the desired seed to seed distance during sowing. The wheel actuates the flap gates provided at dropping mechanism and the seeds drop out every time the gate is open. By fixing wheels with different spacing of teeth, any desired seed to seed distance can be obtained which makes the seed drill suitable for sowing close growing crops like wheat and row crops like maize, cotton and sorghum etc.

Intercropping is a method of crop production where an extra crop or an inter crop is grown in between the main crop. There is a necessity to mechanize the seeding operation. As the present seed cum fertilizer drills couldn't sow both main as well as intercrop at a time in a intercropping system of agricultural practice, overcome this issue the existing seed drills should be modified to suit the intercropping system of agriculture.

Singh (1971) revealed that by using a seedcum-fertilizer drill for wheat crop there was an increase in yield by 13.25 percent when compared with the conventional method. Sharma et al., (1989) concluded that using the animal drawn mechanical sowing has resulted in 49 per cent savings in the cost of operation in comparison with the traditional method of sowing wheat crop. The overall benefit was Rs.671.75 / ha. Srivastava and Dubey (1985) reported that the draft of a three row animal drawn seed-cum-fertilizer drill (planter) was in the 45-65 $\mathrm{Kg}$ range depending upon the soil type and moisture content. The field capacity of the machine ranged from 0.1 $0.25 \mathrm{ha} / \mathrm{h}$ depending on the row spacing.

\section{Materials and Methods}

The bullock drawn seed cum fertilizer drill was modified as per the requirement of the intercropping practices. The seed drill was modified for the intercropping ratio of 2:1 and 8:1.

The specifications of the seed cum fertilizer drill as follows:

a. Dimensions (L X W X H) mm 1015 X 900 X 950

b. Weight of the implement $-50 \mathrm{~kg}$.

c. Row to row spacing - Adjustable (220 \& $450 \mathrm{~mm})$.

d. Number of furrow openers - 3

e. Seed metering mechanism- fluted roller of $4 \mathrm{~cm}$ diameter with 12 flutes

f. Fertilizer metering mechanism fluted roller of $4 \mathrm{~cm}$ diameter with 8 flutes

g. Power transmission - Seed and fertilizer metering mechanisms are driven by ground wheel with chain and sprocket.

h. Hopper capacity $=0.048$ cu.m (0.024 cu.m each i.e. both seed hopper and fertilizer).

i. Power source $=$ A pair of bullock . 
The seed drill was been equipped with fluted roller seed metering mechanism as shown in Fig. 1. The length of the roller exposed to the seeds can be controlled by a level to adjust the flow of seeds as well as for fertilizer to control the seed and fertilizer rate, respectively. The top view and side of the bullock drawn seed cum fertilizer drill are shown in Fig. 2 and Fig. 3, respectively.

The hopper was partitioned in 3 parts with two movable trapezoidal MS plates through a screw mechanism as shown in Fig. 4, where the centre portion was filled with the main crop where as either portions are filled with intercrop. The partitioned hopper is shown in Fig. 5. The MS plates provided in the hopper can be easily movable so as to allow the main crop seeds or the intercrop seeds to flow to the metering mechanism through a long threaded screw which is operated by a handle provided at the either side of the hopper. The modified and calibrated bullock drawn seed cum fertilizer drill was evaluated in the field to check its performance with a pair of bullock and a labour.

\section{Results and Discussion}

The modified seed drill was calibrated in the laboratory to determine the seed rate of redgam and soyabean. The calibration was done at two speeds i.e. $3 \mathrm{kmph}$ and $5 \mathrm{kmph}$. The average seed rate of redgram at $3 \mathrm{kmph}$ and $5 \mathrm{kmph}$ were found to be $15.3 \mathrm{~kg} / \mathrm{ha}$ and $14.5 \mathrm{~kg} / \mathrm{ha}$, respectively. The details of calibration of redgram at $3 \mathrm{kmph}$ and $5 \mathrm{kmph}$ are shown in Table 1 and 2, respectively. The variation of droppings of redgram in three different furrow opener were found to be less than $10 \%$ as recommended by BIS.

Table.1 Summary of calibration of redgram at $3.0 \mathrm{kmph}$

\begin{tabular}{|c|c|c|c|c|c|c|c|c|}
\hline \multirow[t]{2}{*}{$\begin{array}{l}\text { Level of } \\
\text { seed in } \\
\text { hopper }\end{array}$} & \multirow[t]{2}{*}{$\begin{array}{c}\text { Seed } \\
\text { discharge } \\
\text { setting }\end{array}$} & \multicolumn{3}{|c|}{$\begin{array}{l}\text { Weight of seed from furrow } \\
\text { openers, (g) }\end{array}$} & \multicolumn{3}{|c|}{$\begin{array}{l}\text { Variation from } \\
\text { mean, }(\%)\end{array}$} & \multirow[t]{2}{*}{$\begin{array}{l}\text { Seed } \\
\text { rate } \\
\mathrm{kg} / \mathrm{hr}\end{array}$} \\
\hline & & 1 & 2 & 3 & 1 & 2 & 3 & \\
\hline \multirow[t]{3}{*}{ Full } & Minimum & 76.5 & 75.8 & 82.4 & 1.1 & 2.0 & -6.6 & 15.3 \\
\hline & Medium & 76.2 & 75.8 & 75.4 & -0.4 & 0.1 & 0.7 & 15.1 \\
\hline & Maximum & 75.7 & 75.6 & 75.9 & -0.4 & -0.2 & -0.6 & 15.2 \\
\hline \multirow[t]{3}{*}{$3 / 4^{\text {th }}$} & Minimum & 75.1 & 75.6 & 74.5 & 0.3 & -0.4 & 1.1 & 15.4 \\
\hline & Medium & 74.5 & 74.6 & 75.1 & 0.4 & 0.2 & -0.4 & 15.2 \\
\hline & Maximum & 74.6 & 73.5 & 75.1 & -0.5 & 1.0 & -1.1 & 15.3 \\
\hline \multirow[t]{3}{*}{$1 / 2$} & Minimum & 73.5 & 73.6 & 74.5 & 0.4 & 0.3 & -0.9 & 15.5 \\
\hline & Medium & 73.2 & 72.8 & 73.6 & -0.1 & 0.5 & -0.6 & 14.9 \\
\hline & Maximum & 72.8 & 72.6 & 73.4 & 0.4 & 0.7 & -0.4 & 15.1 \\
\hline \multirow[t]{3}{*}{$1 / 4^{\text {th }}$} & Minimum & 72.9 & 75.2 & 72.4 & -0.2 & -3.3 & 0.5 & 15.0 \\
\hline & Medium & 72.2 & 72.6 & 71.6 & 0.0 & -0.6 & 0.8 & 15.3 \\
\hline & Maximum & 71.5 & 72.1 & 71.5 & 0.3 & -0.5 & 0.3 & 15.2 \\
\hline
\end{tabular}


Table.2 Summary of calibration of redgram at $5.0 \mathrm{kmph}$

\begin{tabular}{|c|c|c|c|c|c|c|c|c|}
\hline \multirow[t]{2}{*}{$\begin{array}{l}\text { Level of } \\
\text { seed in } \\
\text { hopper }\end{array}$} & \multirow[t]{2}{*}{$\begin{array}{c}\text { Seed discharge } \\
\text { setting }\end{array}$} & \multicolumn{3}{|c|}{$\begin{array}{l}\text { Weight of seed from furrow } \\
\text { openers, (g) }\end{array}$} & \multicolumn{3}{|c|}{$\begin{array}{l}\text { Variation from } \\
\text { mean, }(\%)\end{array}$} & \multirow[t]{2}{*}{$\begin{array}{c}\text { Seed } \\
\text { rate } \\
\mathrm{kg} / \mathrm{ha}\end{array}$} \\
\hline & & 1 & 2 & 3 & 1 & 2 & 3 & \\
\hline \multirow{3}{*}{ Full } & Minimum & 78.9 & 78.6 & 78.4 & -1.5 & 1.6 & 0.9 & 14.5 \\
\hline & Medium & 78.2 & 78.4 & 77.6 & -0.1 & -0.4 & 0.6 & 14.6 \\
\hline & Maximum & 77.8 & 78.1 & 77.4 & -0.1 & -0.5 & 0.4 & 14.4 \\
\hline \multirow[t]{3}{*}{$3 / 4^{\text {th }}$} & Minimum & 77.6 & 77.4 & 78.5 & -0.1 & 0.2 & -1.2 & 14.7 \\
\hline & Medium & 76.4 & 77.1 & 76.5 & 0.5 & -0.4 & 0.4 & 14.3 \\
\hline & Maximum & 76.2 & 76.4 & 75.8 & -0.4 & -0.7 & 0.1 & 14.5 \\
\hline \multirow[t]{3}{*}{$1 / 2$} & Minimum & 75.8 & 75.9 & 76.8 & 0.3 & 0.1 & -1.1 & 14.7 \\
\hline & Medium & 75.2 & 75.1 & 75.8 & 0.0 & 0.2 & -0.8 & 14.3 \\
\hline & Maximum & 74.5 & 74.2 & 73.8 & -0.1 & 0.3 & 0.8 & 14.5 \\
\hline \multirow[t]{3}{*}{$1 / 4^{\text {th }}$} & Minimum & 74.2 & 73.5 & 74.1 & -0.5 & 0.4 & -0.4 & 14.6 \\
\hline & Medium & 73.8 & 73.8 & 73.4 & -0.9 & -0.9 & -0.4 & 14.3 \\
\hline & Maximum & 73.2 & 72.5 & 73.6 & 1.1 & 2.1 & 0.6 & 14.2 \\
\hline
\end{tabular}

Table.3 Summary of calibration of soyabean at $3.0 \mathrm{kmph}$

\begin{tabular}{|c|c|c|c|c|c|c|c|c|}
\hline \multirow{2}{*}{$\begin{array}{l}\text { Level of } \\
\text { seed in } \\
\text { hopper }\end{array}$} & \multirow{2}{*}{$\begin{array}{c}\text { Seed } \\
\text { discharge } \\
\text { setting }\end{array}$} & \multicolumn{3}{|c|}{$\begin{array}{c}\text { Weight of seed from furrow } \\
\text { openers, (g) }\end{array}$} & \multicolumn{3}{|c|}{$\begin{array}{l}\text { Variation from } \\
\text { mean, }(\%)\end{array}$} & \multirow{2}{*}{$\begin{array}{c}\text { Seed } \\
\text { rate } \\
\mathrm{kg} / \mathrm{ha}\end{array}$} \\
\hline & & 1 & 2 & 3 & 1 & 2 & 3 & \\
\hline \multirow[t]{3}{*}{ Full } & Minimum & 42.5 & 43.6 & 43.8 & 2.2 & -0.3 & -0.8 & 45.6 \\
\hline & Medium & 42.1 & 42.8 & 42.6 & 1.5 & -0.1 & 0.3 & 45.2 \\
\hline & Maximum & 41.5 & 41.6 & 42.8 & 1.1 & 0.9 & -2.0 & 45.4 \\
\hline \multirow[t]{3}{*}{$3 / 4^{\text {th }}$} & Minimum & 41.2 & 42.1 & 41.9 & 1.4 & -0.7 & -0.2 & 45.5 \\
\hline & Medium & 39.5 & 41.7 & 41.2 & 3.2 & -2.2 & -1.0 & 45.4 \\
\hline & Maximum & 39.5 & 39.8 & 39.4 & 0.6 & -0.2 & 0.9 & 45.1 \\
\hline \multirow[t]{3}{*}{$1 / 2$} & Minimum & 39.2 & 39.5 & 39.8 & 0.8 & 0.1 & -0.7 & 45.3 \\
\hline & Medium & 38.2 & 38.6 & 39.4 & 2.0 & 1.0 & -1.1 & 45.7 \\
\hline & Maximum & 37.8 & 38.2 & 38.1 & 2.0 & 0.9 & 1.2 & 45.2 \\
\hline \multirow[t]{3}{*}{$1 / 4^{\text {th }}$} & Minimum & 37.6 & 37.5 & 36.8 & -0.4 & -0.1 & 1.8 & 45.7 \\
\hline & Medium & 37.5 & 37.1 & 37.6 & 0.1 & 1.2 & -0.2 & 45.9 \\
\hline & Maximum & 36.5 & 36.8 & 35.9 & -3.4 & -0.9 & -1.7 & 45.1 \\
\hline
\end{tabular}


Table.4 Summary of calibration of soyabean at $5.0 \mathrm{kmph}$

\begin{tabular}{|c|c|c|c|c|c|c|c|c|}
\hline \multirow{2}{*}{$\begin{array}{l}\text { Level of } \\
\text { seed in } \\
\text { hopper }\end{array}$} & \multirow{2}{*}{$\begin{array}{c}\text { Seed } \\
\text { discharge } \\
\text { setting }\end{array}$} & \multicolumn{3}{|c|}{$\begin{array}{c}\text { Weight of seed from furrow } \\
\text { openers, }(\mathrm{g})\end{array}$} & \multicolumn{3}{|c|}{$\begin{array}{l}\text { Variation from } \\
\text { mean, }(\%)\end{array}$} & \multirow{2}{*}{$\begin{array}{c}\text { Seed } \\
\text { rate } \\
\mathrm{kg} / \mathrm{ha}\end{array}$} \\
\hline & & 1 & 2 & 3 & 1 & 2 & 3 & \\
\hline \multirow[t]{3}{*}{ Full } & Minimum & 45.6 & 45.2 & 44.6 & -0.4 & 0.5 & 1.8 & 44.5 \\
\hline & Medium & 45.2 & 44.3 & 44.5 & -0.8 & 1.2 & 0.7 & 44.1 \\
\hline & Maximum & 44.2 & 44.6 & 44.9 & 1.2 & 0.3 & -0.4 & 44.3 \\
\hline \multirow[t]{3}{*}{$3 / 4^{\text {th }}$} & Minimum & 44.2 & 43.6 & 43.8 & -0.5 & 0.9 & 0.4 & 44.5 \\
\hline & Medium & 43.6 & 43.2 & 43.5 & -0.2 & 0.7 & 0.0 & 44.8 \\
\hline & Maximum & 43.2 & 42.5 & 45.2 & 0.5 & 2.1 & -4.1 & 44.7 \\
\hline \multirow[t]{3}{*}{$1 / 2$} & Minimum & 43.1 & 42.6 & 42.8 & 0.2 & 1.3 & 0.9 & 44.9 \\
\hline & Medium & 42.8 & 43.2 & 42.8 & -0.2 & -1.2 & -0.2 & 44.1 \\
\hline & Maximum & 42.6 & 43.5 & 41.5 & 0.1 & -2.0 & 2.7 & 44.6 \\
\hline \multirow[t]{3}{*}{$1 / 4^{\text {th }}$} & Minimum & 42.2 & 41.6 & 41.8 & -0.6 & 0.9 & 0.4 & 44.2 \\
\hline & Medium & 41.6 & 41.5 & 42.1 & -0.1 & 0.1 & -1.3 & 44.1 \\
\hline & Maximum & 40.6 & 40.7 & 39.5 & -0.2 & -0.4 & 2.5 & 44.3 \\
\hline
\end{tabular}

Table.5 Summary of calibration of urea at $3.0 \mathrm{kmph}$

\begin{tabular}{|c|c|c|c|c|c|c|c|c|}
\hline \multirow{2}{*}{$\begin{array}{c}\text { Level of } \\
\text { fertilizer in } \\
\text { hopper }\end{array}$} & \multirow{2}{*}{$\begin{array}{c}\text { Fertilizer } \\
\text { discharge } \\
\text { setting }\end{array}$} & \multicolumn{3}{|c|}{$\begin{array}{l}\text { Weight of seed from furrow } \\
\text { openers, (g) }\end{array}$} & \multicolumn{3}{|c|}{$\begin{array}{l}\text { Variation from } \\
\text { mean, }(\%)\end{array}$} & \multirow{2}{*}{$\begin{array}{c}\text { fertilizer } \\
\text { rate } \\
\mathrm{kg} / \mathrm{ha}\end{array}$} \\
\hline & & 1 & 2 & 3 & 1 & 2 & 3 & \\
\hline \multirow[t]{3}{*}{ Full } & Minimum & 48.5 & 49.4 & 48.6 & -0.3 & -2.2 & -0.5 & 70.9 \\
\hline & Medium & 48.2 & 47.2 & 46.5 & -1.7 & 0.4 & 1.9 & 70.8 \\
\hline & Maximum & 47.3 & 46.5 & 46.8 & -0.9 & 0.8 & 0.1 & 70.5 \\
\hline \multirow[t]{3}{*}{$3 / 4^{\text {th }}$} & Minimum & 46.8 & 45.9 & 46.7 & -1.7 & 0.3 & -1.5 & 70.2 \\
\hline & Medium & 45.3 & 45.8 & 46.1 & 2.0 & 0.9 & 0.3 & 69.8 \\
\hline & Maximum & 45.1 & 45.2 & 44.6 & -0.3 & -0.5 & 0.8 & 69.4 \\
\hline \multirow[t]{3}{*}{$1 / 2$} & Minimum & 44.9 & 44.8 & 45.2 & -0.4 & -0.2 & -1.1 & 69.5 \\
\hline & Medium & 44.8 & 44.1 & 43.5 & -1.0 & 0.6 & 1.9 & 69.2 \\
\hline & Maximum & 44.1 & 43.8 & 44.1 & -1.3 & -0.6 & -1.3 & 68.5 \\
\hline \multirow[t]{3}{*}{$1 / 4^{\text {th }}$} & Minimum & 43.8 & 44.1 & 43.6 & -0.3 & -1.0 & 0.1 & 68.2 \\
\hline & Medium & 42.8 & 42.8 & 43.6 & 0.5 & 0.5 & -1.3 & 68.0 \\
\hline & Maximum & 42.1 & 42.9 & 43.8 & 1.6 & -0.2 & -2.3 & 67.2 \\
\hline
\end{tabular}


Table.6 Summary of calibration of urea at $5.0 \mathrm{kmph}$

\begin{tabular}{|c|c|c|c|c|c|c|c|c|}
\hline \multirow[t]{2}{*}{$\begin{array}{l}\text { Level of } \\
\text { fertilizer in } \\
\text { hopper }\end{array}$} & \multirow[t]{2}{*}{$\begin{array}{c}\text { Fertilizer } \\
\text { discharge } \\
\text { setting }\end{array}$} & \multicolumn{3}{|c|}{$\begin{array}{l}\text { Weight of seed from furrow } \\
\text { openers, (g) }\end{array}$} & \multicolumn{3}{|c|}{$\begin{array}{l}\text { Variation from } \\
\text { mean, }(\%)\end{array}$} & \multirow[t]{2}{*}{$\begin{array}{l}\text { fertilizer } \\
\text { rate } \mathrm{kg} / \mathrm{ha}\end{array}$} \\
\hline & & 1 & 2 & 3 & 1 & 2 & 3 & \\
\hline \multirow[t]{3}{*}{ Full } & Minimum & 52.6 & 52.8 & 51.6 & 0.4 & 0.0 & 2.3 & 73.6 \\
\hline & Medium & 51.6 & 52.9 & 53.4 & 1.6 & -0.8 & -1.8 & 73.4 \\
\hline & Maximum & 51.2 & 52.6 & 52.4 & 3.5 & 0.8 & 1.2 & 73.2 \\
\hline \multirow[t]{3}{*}{$3 / 4^{\text {th }}$} & Minimum & 50.6 & 51.6 & 51.8 & 2.8 & 0.8 & 0.5 & 72.6 \\
\hline & Medium & 49.8 & 49.5 & 49.5 & 0.9 & 1.5 & 1.5 & 72.1 \\
\hline & Maximum & 49.5 & 48.9 & 50.2 & 0.3 & 1.5 & -1.1 & 72.0 \\
\hline \multirow[t]{3}{*}{$1 / 2$} & Minimum & 49.2 & 49.1 & 49.8 & 0.9 & 1.1 & -0.3 & 71.9 \\
\hline & Medium & 48.9 & 49.5 & 48.6 & -0.7 & -1.9 & 0.0 & 71.6 \\
\hline & Maximum & 48.6 & 48.6 & 47.9 & -0.1 & -0.1 & 1.4 & 71.5 \\
\hline \multirow[t]{3}{*}{$1 / 4^{\text {th }}$} & Minimum & 48.2 & 48.1 & 47.5 & -0.3 & -0.1 & 1.2 & 71.2 \\
\hline & Medium & 48.1 & 47.2 & 47.6 & -1.1 & 0.8 & -0.1 & 71.1 \\
\hline & Maximum & 47.5 & 49.1 & 47.6 & 0.6 & -2.8 & 0.4 & 70.6 \\
\hline
\end{tabular}

Fig.1 Fluted roller type metering mechanism

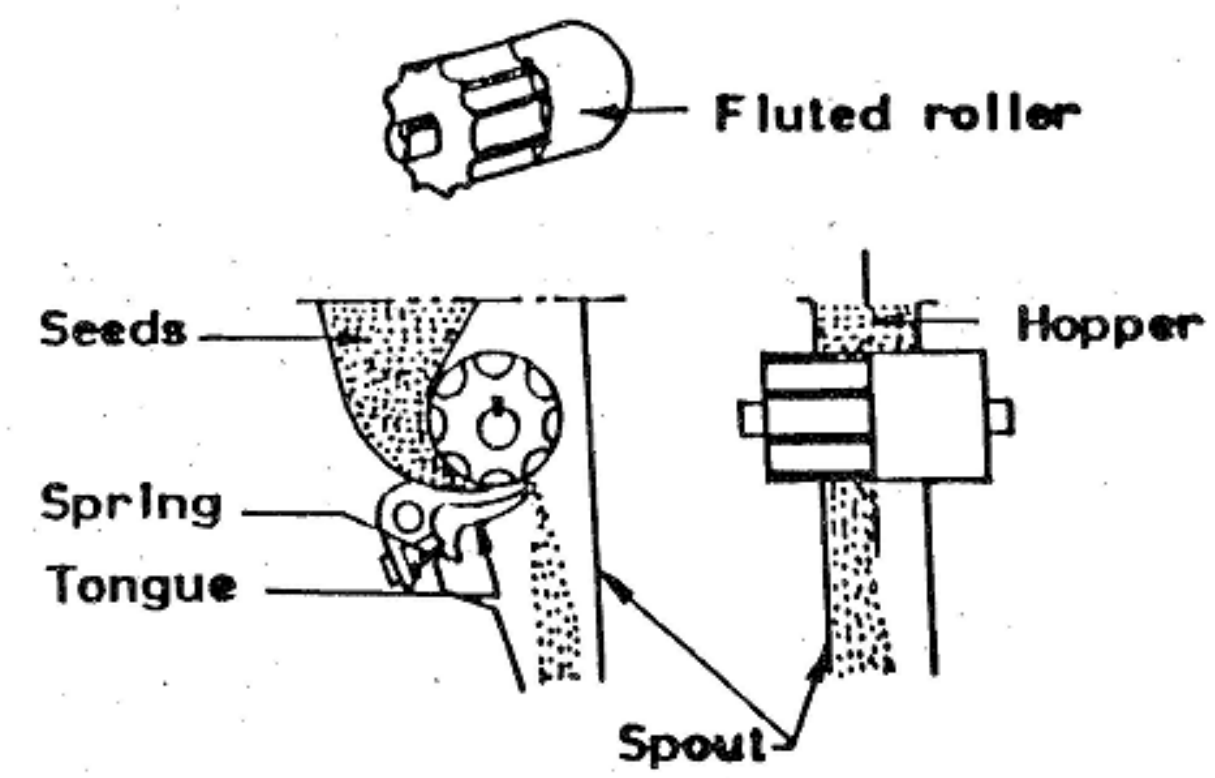


Fig.2 Top view of seed drill

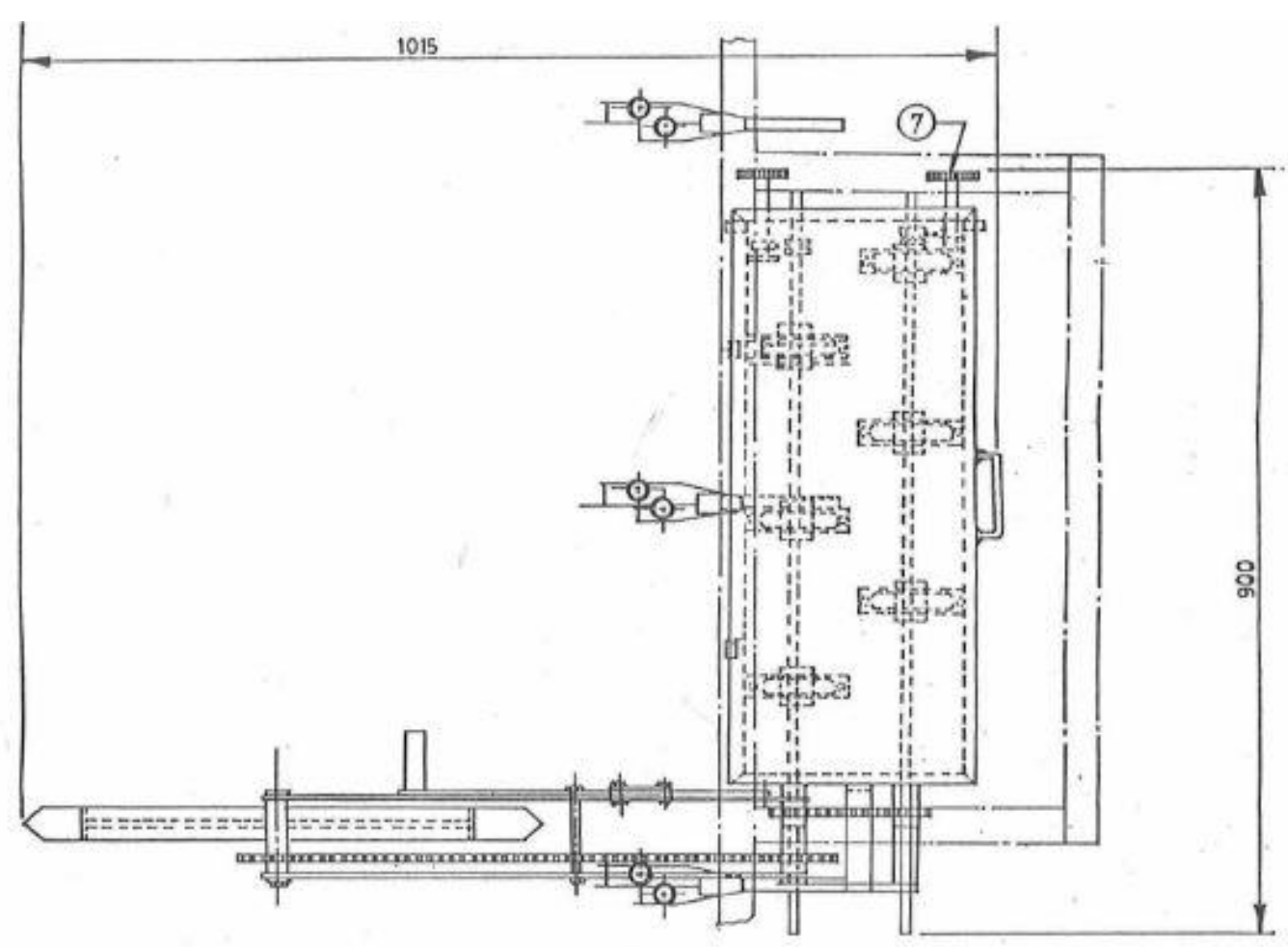

Fig.3 Side view of seed drill

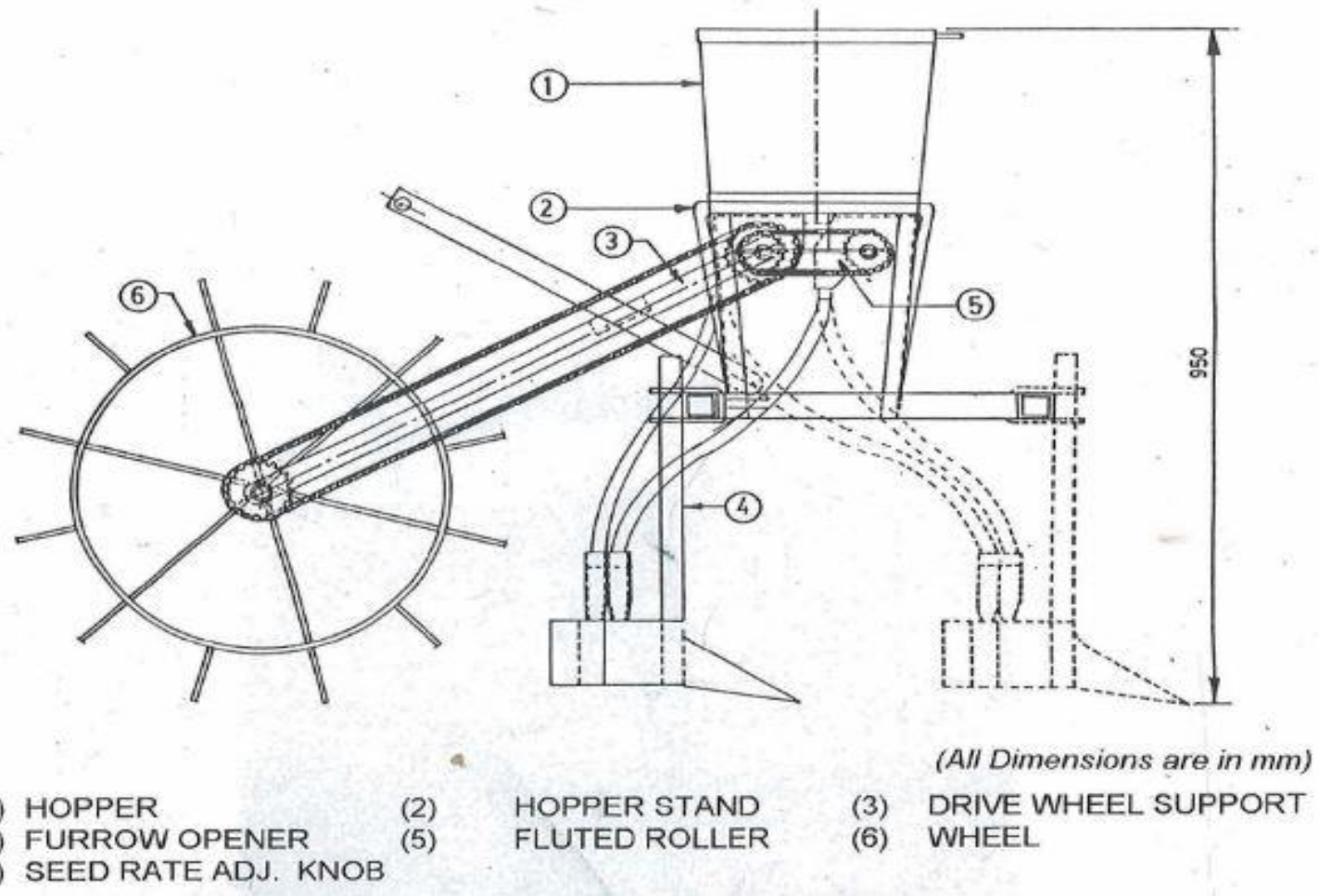


Fig.4 MS Plate

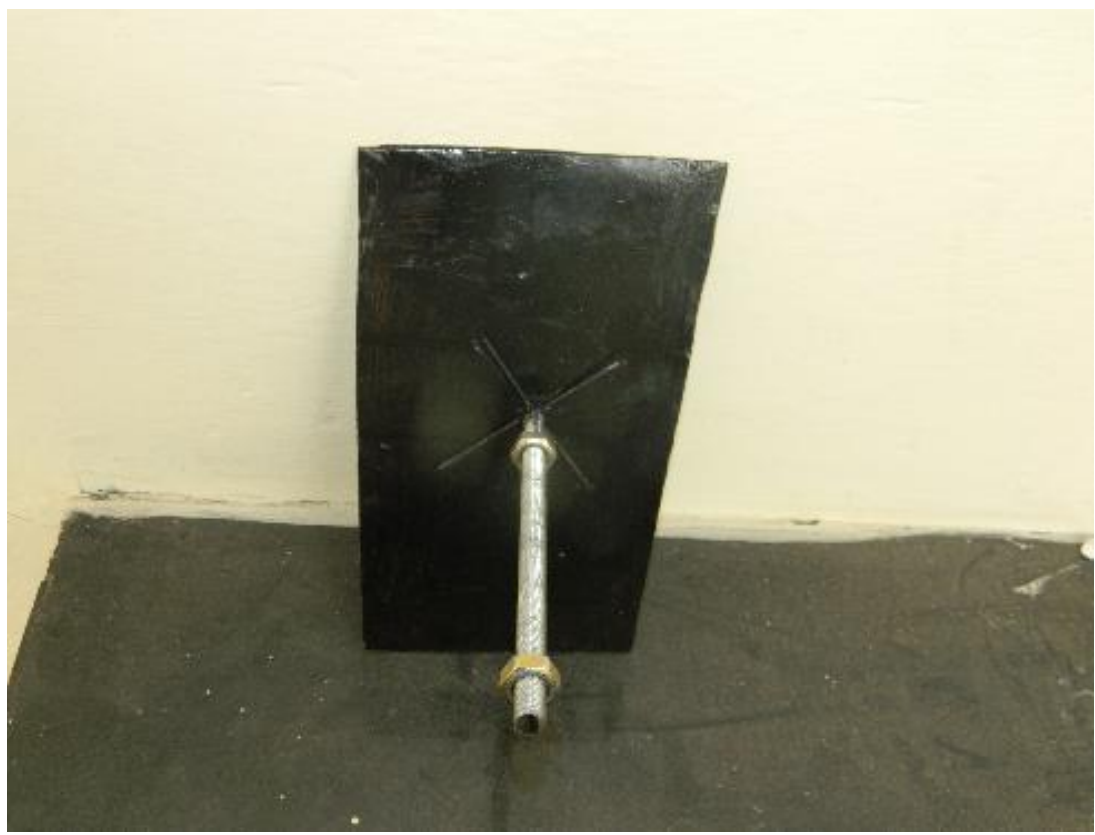

Fig.5 Top view of the partioned hopper

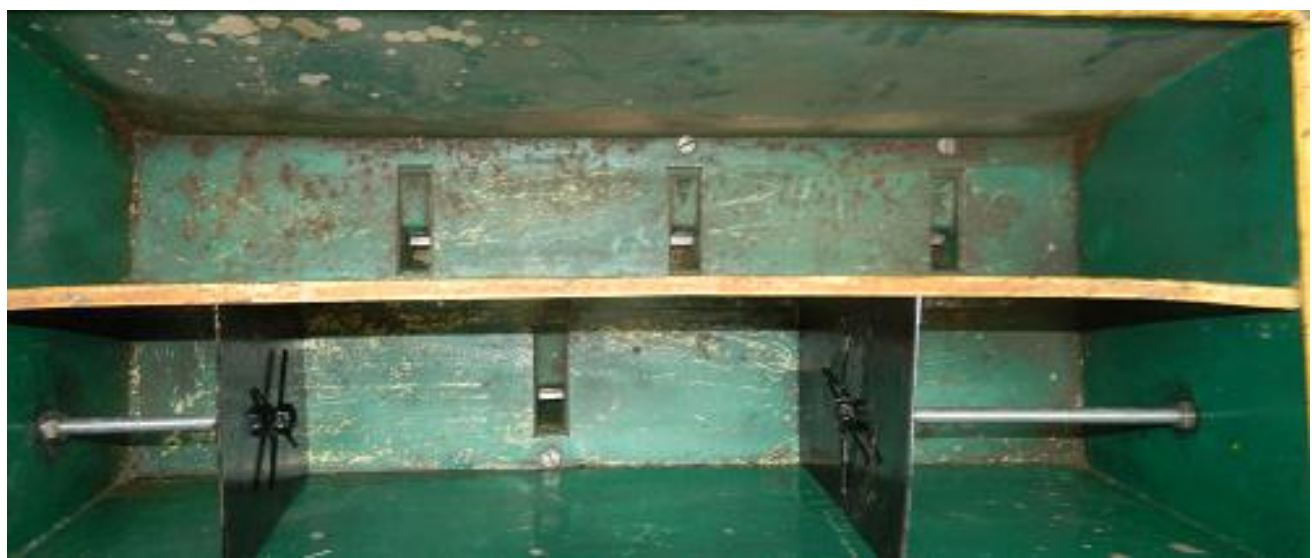

The average seed rate of soyabean at $3 \mathrm{kmph}$ and $5 \mathrm{kmph}$ were found to be $45.35 \mathrm{~kg} / \mathrm{ha}$ and $44.5 \mathrm{~kg} / \mathrm{ha}$, respectively. The details of calibration of redgram at $3 \mathrm{kmph}$ and $5 \mathrm{kmph}$ are shown in Table 3 and 4, respectively. The variation of droppings of soyabean in three different furrow opener were found to be less than $10 \%$ as recommended by BIS.

The flow of fertilizer was also calibrated using urea. The detailed calibration results of urea at $3 \mathrm{kmph}$ and $5 \mathrm{kmph}$ are shown in Table 5 and 6 . The average urea rate were found to $69.5 \mathrm{~kg} / \mathrm{ha}$ and $70.3 \mathrm{~kg} / \mathrm{ha}$ for 3 $\mathrm{kmph}$ and $5 \mathrm{kmph}$, respectively. The variation of droppings of urea in three different furrow opener were found to be less than $10 \%$ as recommended by BIS.

The modified seed cum fertilizer drill was evaluated in the field to check its performance. The average field capacity of 
the implement was found to be $0.25 \mathrm{ha} / \mathrm{h}$ at a forward speed of $2.8 \mathrm{kmph}$ with a field efficiency was found to be $70 \%$. The average draft requirement of the equipment was recorded as $900 \mathrm{~N}$.

In conclusion, the seed cum fertilizer drill was successfully modified to suit inter cropping system. The seed rate and fertilizer rate of application were found to be within the acceptable limits. The overall performance of the equipment was found to be satisfactory and has gained popularity among the farmers in large extent.

\section{References}

Kumar, A. and Umran, A. H., 2013, Design, development and performance evaluation of fertilizer band placement cum earthing machine for maize. Int. J. Agril. Innov. Res., 4(2): 120-125.

Laghari, M., Laghari, N., Shah, A. R. and Chandio, F. A., 2014, Calibration and performance of tractor mounted rotary fertilizer spreader. Int. J. Adv. Res., New York., 2(4): 839-846.

Magar, A. P., Bhuthada. S. H. and Abuj, M. D., 2010, Performance evaluation of bullock drawn seed drills for ground nut

Mandal, S. and Thakur, T. C., 2010, Design and development of subsoiler-cumdifferential rate fertilizer applicator. Agril. Engg. Intl.CIGR J., 12(1): 31-38.

Manpreet, S., 2015, Design and development of tractor operated seeder for wheat as relay crop in cotton. Published Ph.D. (Agril. Engg.) Thesis, Punjab Agricultural University, Ludhiana.

Mehta, M. L., Verma, S. R., Mishra, S. R. and Sharma, V. K., 2005, Testing and evaluation of agricultural machinery. Daya Publishing House, Delhi-100 035.

Sahay, J., 2006, Elements of Agricultural Engineering. Standard Publishers Distributors.

Sharma, N. D. and Mukesh, S, 2008, A text book Farm machinery design principles and problems. Jain brother's publications

Singh, J. and Nikhade, J. S., 2014, Calibration and field performance of seed cum fertilizer drill for paddy cultivation. Int. J. Engg. Sci. Res. Tec., 3(5): 611-615.

Singh, J. and Yadaw, M., 2014, Testing and evaluation of animal drawn multipurpose tool seed cum fertilizer drill. Int. J. Sci. Engg Tech., 3(5): 463-466.

Thakur, T. C., 1985, Design aspects of soil engaging hand tools. Agric. Engg. Today. 21: 15-18.

\section{How to cite this article:}

Revanth, K., S. Ramyashree, K. Sai Krishna, B. T. Rakesh, D. Sandhya and Murkannappa. 2020. Modification of Bullock Drawn Seed cum Fertilizer Drill for Intercropping System. Int.J.Curr.Microbiol.App.Sci. 9(02): 568-576. doi: https://doi.org/10.20546/ijcmas.2020.902.071 